\title{
Pregabalin Antagonizes Copper-Induced Toxicity in the Brain: In vitro and in vivo Studies
}

\author{
D. Marmolino ${ }^{\mathrm{a}}$ M. Manto ${ }^{\mathrm{a}, \mathrm{b}}$ \\ ${ }^{a}$ Laboratoire de Neurologie Expérimentale, ULB-Erasme, and ${ }^{b}$ FNRS, Fonds National pour la Recherche \\ Scientifique, Bruxelles, Belgium
}

\section{Key Words}

Pregabalin · Copper - Glutamate - Nitric oxide $\cdot$ NMDA •

Transcription

\begin{abstract}
Background: Copper plays key roles in brain metabolism. Disorders of copper metabolism impact on neural signaling. The intracellular and extracellular concentrations of copper are tightly regulated. Pregabalin is a drug with multiple modes of action and has a high-affinity binding site for the alpha2delta subunit of voltage-gated calcium channels. Methods: Assessment of neuroprotective effects of pregabalin using cell culture, transcription studies, microdialysis and neurophysiological assessment in rats. Results: In vitro, copper decreased markedly the survival of neuronal cells and enhanced the production of nitric oxide (NO). Transcription of NO synthase (NOS) 1-3 and PGC-1a (a key regulator of mitochondrial biogenesis) was activated. In vivo, copper impaired the NMDA-mediated regulation of glutamate in the brain, increased the production of NO and enhanced markedly the excitability of the motor cortex. Pregabalin had antagonistic effects both in vitro and in vivo. Conclusion: Our experiments highlight that pregabalin antagonizes the neurotoxic effects of copper. We argue that pregabalin exerts
\end{abstract}

\section{KARGER}

Fax +4161306 1234

E-Mail karger@karger.ch

www.karger.com
(C) 2010 S. Karger AG, Basel

$1424-862 X / 10 / 0184-0210 \$ 26.00 / 0$

Accessible online at:

www.karger.com/nsg neuroprotective effects by silencing the overexcitability state induced by copper. We propose a possible use of pregabalin for treatment of disruption of copper homeostasis.

Copyright $\odot 2010$ S. Karger AG, Basel

\section{Introduction}

Copper is a metal ion playing major roles in brain metabolism [1]. Copper is a cofactor required for structural and catalytic properties of key enzymes involved in oxidative phosphorylation, synthesis of proteins and modulation of neurotransmission [2,3]. Free copper concentrations in normal cells are controlled at very low levels; probably less than one atom per cell [4]. In serum, about $65-90 \%$ of copper tightly binds with ceruloplasmin. The rest loosely binds with albumin, transcuprein and amino acids [5]. Copper is transported through the blood-brain barrier as free copper [1]. The cellular uptake of copper is mediated by the high-affinity copper transporter 1 (CuTr1) and the nonspecific divalent metal transporter 1 (DMT1) [6]. Copper efflux is supervised by the ATPase, copper transport protein alpha (ATP7A) and beta (ATP7B) [7]. Copper in excess interacts with oxygen and generates reactive species such as $\mathrm{H}_{2} \mathrm{O}_{2}, \mathrm{O}_{2}^{-}$and $\mathrm{OH}^{*}$ 
which are major players in excitotoxicity $[8,9]$. Copper overload induces mitochondrial dysfunction, lipid peroxidation, and formation of 4-hydroxy nonenal, an inhibitor of pyruvate dehydrogenase and alpha-ceto-glutarate dehydrogenase [10-13].

Several neurodegenerative diseases are characterized by impaired copper homeostasis [8]. In Wilson's disease, copper overload induces a liver failure and damages the central nervous system, causing increased free radical generation, lipid peroxidation and mitochondrial dysfunction [14-16]. Copper toxicity participates also in the pathogenesis of disorders characterized by familial mutations in the $\mathrm{Cu}$-zinc superoxide dismutase (SOD1) gene [17]. SOD1 turns into a pro-oxidant enzyme, with production of reactive oxygen species (ROS) [9]. The onset of Parkinson's disease and Alzheimer's disease might also be associated with a disorder of copper metabolism $[9,18$, 19]. Another brain structure which might be vulnerable to copper is the cerebellum. We have observed a form of cerebellar ataxia associated with hypercupremia (HICA syndrome: hypercupremia-induced cerebellar ataxia). Hypercupremia might decompensate a cerebellar syndrome of other origin, since depletion of copper with supplements of zinc reduces the severity of cerebellar ataxia (unpublished data). This form of cerebellar ataxia might be related to a direct toxicity of free copper. Interestingly, cerebellar nuclei are enriched in copper, especially in the periphery, in zinc and iron $[2,20]$. The distribution of copper is impaired in brain and spinal cord of spinocerebellar ataxia [21].

Pregabalin (S-3-aminomethyl-5-methylhexanoic acid, known as S-3-isobutyl GABA), is a molecule with multiple modes of action and binding to the alpha2-delta subunit of voltage-gated calcium channels [22]. The drug is widely used for seizures, pain and anxiety. Pregabalin reduces the release of neurotransmitters, primarily glutamate. Its action depends upon NMDA receptor activation [22]. Given its mechanism of action and given that the drug targets in particular the presynaptic sites of synapses in vivo, we tested the hypothesis that it might counteract the deleterious cascade of events triggered by copper.

The goals of the present study were the following:

(1) To improve our understanding of the signaling in cases of copper toxicity, in particular the modulation of glutamate signaling. For in vitro studies, we investigated the toxic effects of copper on human neuroblastoma cells. We characterized the copper effects on the transcription of the 3 isoforms of the nitric oxide (NO) synthase (neuronal NOS1, inducible NOS2, and endothelial NOS3), the mitochondrial biogenesis' key regulator PGC-1a (peroxi- some proliferator activated-receptor gamma cofactor alpha) and the mitochondrial superoxide dismutase (SOD2). For in vivo studies, we studied the effects of copper on the NMDA-mediated regulation of glutamate in the brain. We also investigated the effects of copper on the excitability of motor cortex.

(2) To test the hypothesis that pregabalin exerts a protective effect, antagonizing both in vitro and in vivo effect of copper.

\section{Materials and Methods}

Studies were approved by the Animal Care Committee of the Free University of Brussels.

\section{In vitro Experiments}

Cell Culture

SKNBE cells (human neuroblastoma cell line [23]) were grown in DMEM supplemented with $10 \%$ fetal bovine serum (FBS), $2 \mathrm{mM} \mathrm{L}$-glutamine, $100 \mathrm{U} / \mathrm{ml}$ penicillin and streptomycin. All the experiments with copper were conducted 1 day after the incubation in a penicillin/streptomycin-free media culture. SKNBE cells were incubated with 1-5-10-50-100-200-500 $\mu \mathrm{M}$ of copper (II) sulphate (Sigma) dissolved directly in DMEM-free cell media culture for 24, 48 and $72 \mathrm{~h}$. APV (2-amino-5-phosphonopentanoic acid, an NMDA receptor antagonist; Sigma) and DNQX (6,7-dinitro-quinoxaline-2,3(1H,4H)-dione, an AMPA receptor antagonist; Sigma) were used at concentrations of 250 and $500 \mu \mathrm{M}$, respectively. At the end of the incubation, total cell count (Trypan blue assay assessing cell viability; count of viable control cells normalized to 1) and total RNA extraction (see below) were performed. We also studied the effects of potassium chloride ( $\mathrm{KCl}$; Sigma) in SKNBE cells [24]. Indeed, $\mathrm{KCl}$ induces a membrane depolarization, causing an opening of calcium channels [24]. Cells were cultured with $20 \mathrm{mM} \mathrm{KCl}$ alone or in combination with 500 $\mu \mathrm{M}$ copper and $500 \mu \mathrm{M}$ pregabalin for $5 \mathrm{~h}$ before total RNA extraction.

\section{Real-Time PCR}

Total mRNA was extracted with the RNeasy mini Kit (Qiagen). Total RNA was incubated with the DNase set (Qiagen) before retro-transcription. $1 \mu \mathrm{g}$ of total RNA was reverse-transcribed using the reverse-transcriptase M-MLV superscript II (Invitrogen). Approximately $50 \mathrm{ng}$ of cDNA were amplified by real-time PCR using a Power SYBER Green master Mix (Applied Biosystems). Primers for the NOS1, NOS2, NOS3, PGC-1a, SOD2 genes and for the reference gene ( $\beta$-actin) were obtained from Qiagen. GAPDH was also used as reference gene to confirm the results. Each sample was run in triplicate in a $20 \mu \mathrm{l}$ reaction. All reactions were performed in an ABIPrism 7500 sequence detector system. Quantitative real-time PCR analyses were carried out using the 2(-Delta Delta $\mathrm{C}(\mathrm{T}))$ method $(2-\Delta \Delta \mathrm{Ct})$ [25].

NO Production

NO levels were estimated in SKNBE cells (500,000 cells) maintained in PBS solution. NO concentrations were assessed using an 
ISO-NO microsensor for Apollo-1000 (World Precision Instruments, UK). Calibration was performed using S-nitroso-N-acetyl-penicillamine (SNAP, Sigma) as reported by Alvarez et al. [26]. The lower detection limit of the sensor is less than $100 \mathrm{pM}$ of NO. NO concentrations were expressed as percentages of baseline measurements (mean concentration for the duration of analysis of a period of $15 \mathrm{~s}$ ). We assessed the effects of copper $500 \mu \mathrm{M}$, NMDA $10 \mathrm{mM}$ and the association of copper $500 \mu \mathrm{M}+$ NMDA 10 $\mathrm{mM}$ on the concentrations of $\mathrm{NO}$.

\section{In vivo Experiments}

Microdialysis

Adult Wistar rats (Charles River laboratories) were housed in the local Animal Care Facilities. Rats were anaesthetized with a loading dose of chloral hydrate i.p. (400 mg/kg dissolved in Ringer's solution) and fixed in a stereotactic frame. Rats were kept under general anesthesia using a continuous infusion of chloral hydrate i.p. $2 \mu \mathrm{l} / \mathrm{min}$, in order to obtain stable concentrations of metabolites [27]. Following shaving and dissection of the skin, microdialysis probes were implanted in the left cerebral cortex (coordinates related to Bregma: ant.: $+2.2 \mathrm{~mm}$, lat.: $+0.8 \mathrm{~mm}$, depth: tip of probe at $+2 \mathrm{~mm}$ ) or in left cerebellar nuclei (ant.: $-11.6 \mathrm{~mm}$, lat.: $+2.3 \mathrm{~mm}$, depth: $-5 \mathrm{~mm}$ ). A hole was performed in the skull using a manual drill. Probes (CMA-12, Sweden) were secured with dental cement (Durelon ${ }^{\odot}$, carboxylate cement). Rats were kept over a temperature controller (Heating Controller 872, Harvard Apparatus) during the experiments. Indeed, it has been shown that the temperature is a key-factor for NMDA assessments (the channel kinetics play an important role in determining amplitude and time course of NMDA receptor-mediated postsynaptic currents [28]). The infusion rate of the fluid through the probe was $1 \mu \mathrm{l} / \mathrm{min}$ (CMA 100 microinjection pump, Sweden). Copper was administered by reverse dialysis at a concentration of $71.2 \mu \mathrm{M}$ (dissolved in Ringer's solution; cerebral cortex: 40-80 min; cerebellar nuclei: $20-60 \mathrm{~min}$ ), followed by NMDA infusion $10 \mathrm{mM}$ (dissolved in Ringer's solution; cerebral cortex: from 100 to $160 \mathrm{~min}$; cerebellar nuclei: from 80 to $140 \mathrm{~min}$ ) in order to study the NMDA-mediated regulation of metabolites $[28,29]$. For studies in motor cortex, pregabalin was administered by the i.p. route at 3 doses: 10,30 and $100 \mathrm{mg} / \mathrm{kg}, 20 \mathrm{~min}$ before copper exposure. For studies in cerebellum, we tested (a) the effects of infusion of zinc given the modulatory effects of zinc 14.4 $\mu \mathrm{M}$ upon glutamatergic transmission, especially via NMDA receptors, and the favorable clinical effects of zinc in Wilson's disease with neurological deficits $[14,30]$; the dose of zinc infused by reverse dialysis was based on the estimation of the extracellular concentration of zinc between 10 and $30 \mu \mathrm{M}$, see Kitamura et al. [31]; (b) the effects of 7-nitroindazole $100 \mathrm{mg} / \mathrm{kg}$ i.p. (7-NI, an inhibitor of NOS3); (c) the effects of APV $50 \mu \mathrm{M}$ in loco; (d) the effects of pregabalin alone $30 \mathrm{mg} / \mathrm{kg}$ i.p. at $20 \mathrm{~min}$, and (e) the effects of pregabalin $30 \mathrm{mg} / \mathrm{kg}$ i.p. administered simultaneously with copper. Microdialysates were collected every $20 \mathrm{~min}$ and analyzed for the following metabolites using the CMA 600 device (CMA, Sweden): glutamate, glycerol, lactate, pyruvate, glucose. Linearity regression coefficients $\left(\mathrm{R}^{2}\right)$ determined locally are 0.9984 for glutamate, 0.9991 for glycerol, 1 for lactate and 0.9997 for pyruvate [27]. Each rat was sacrificed at the end of experiments to confirm probe location. Animals were first given a lethal dose of chloral hydrate i.p. and were subsequently decapitated. Brains were dissected and put in isopentane $\left(-80^{\circ} \mathrm{C}\right)$. Only data with the correct probe location (the exposed dialysis membrane located in the target region) were analyzed. Cryosections were performed every $50 \mu \mathrm{m}$.

\section{Measurements of NO in Motor Cortex}

In a first group of rat, we used an infusion of Ringer's solution via the microdialysis probe and measured the concentrations of NO by implanting the NO microsensor (see above) near the extremity of the probe. In a second group, we infused copper 71.2 $\mu \mathrm{M}$ at $20-60 \mathrm{~min}$. In a third group, pregabalin administration $(30 \mathrm{mg} / \mathrm{kg}$ i.p. at $0 \mathrm{~min})$ was followed by infusion of copper $(71.2$ $\mu \mathrm{M}$ at 20-60 min) was applied. Copper was infused in Ringer's solution at a flow rate of $2 \mu \mathrm{l} / \mathrm{min}$. NO measurements were performed every $10 \mathrm{~min}$ from 10 to $60 \mathrm{~min}$.

\section{Excitability of Motor Cortex}

We assessed the effects of infusion of copper in interpositus nucleus upon the excitability of contralateral motor cortex [32]. Corticomuscular responses were assessed (a) before and during intra-nuclear infusion of a control solution (Ringer), (b) before and during intra-nuclear infusion of copper $71.2 \mu \mathrm{M}$, (c) before and after infusion of pregabalin $30 \mathrm{mg} / \mathrm{kg}$ i.p., and (d) before and after administration of pregabalin $30 \mathrm{mg} / \mathrm{kg}$ i.p. followed by intranuclear infusion of copper $71.2 \mu \mathrm{M}$. Infusion rate was $2 \mu \mathrm{l} / \mathrm{min}$.

We investigated the responses in the left gastrocnemius muscle following electrical stimulation of the right motor cortex (NeuroMax 4, Xltek, Canada). We used the location of $3 \mathrm{~mm}$ laterally and $0.5 \mathrm{~mm}$ posterior to the Bregma for stimulation of the motor cortex (duration of stimuli: 1 ms; square waves; NeuroMax 4, Xltek, Canada) [32]. This location is consistent with stimulation sites used in other studies [33]. Recruitment curves (detection of motor threshold MT defined as the lowest intensity eliciting at least 5 of 10 evoked responses with an amplitude $>20 \mu \mathrm{V}$, followed by increases of the intensity of stimulation with steps of $0.1 \mathrm{~mA}$ until a plateau is reached) of corticomotor responses were analyzed to confirm the classical sigmoid course using a sigmoid fitting with 3 parameters: $y=a /(1+\exp (-(x-x 0) / b))$ [34]. Subsequently, motor cortex was stimulated at an intensity of $130 \%$ of MT to assess corticomotor potentials. Peak-to-peak amplitudes in motor responses of the left (right) gastrocnemius muscle were studied for 10 successive corticomotor responses (filter settings were $30 \mathrm{~Hz}$ to $1.5 \mathrm{kHz}$; NeuroMax 4, Xltek, Canada). We used subcutaneous electrodes (Technomed 017 K025) implanted in gastrocnemius muscles. The impedance was kept below $5 \mathrm{k} \Omega$. To record compound muscle action potentials (CMAPs), electrical stimuli were applied (needle electrodes) at the level of the ipsilateral sciatic nerve at about $16 \mathrm{~mm}$ laterally from midline. CMAPs in the left/right gastrocnemius muscles were obtained using electrical stimuli delivered by a stimulation unit (NeuroMax 4, Xltek, Canada) [34].

\section{Statistical Analysis}

Statistical analysis was performed using the Sigma Stat Software.

In vitro studies: To evaluate the statistical significance of the copper effect on cell survival, the analysis of variance was used. Levels of NO in SKNBE cells were compared using the analysis of variance followed by post-hoc test (Holm-Sidak test). For RNA studies, statistical significance was calculated using the analysis of variance. 
Fig. 1. Phase-contrast microscopy of SKNBE cells and cell survival after copper incubation. a SKNBE control cells (Ctrl: not treated cells; magnification: $\times 10$ ). b SKNBE cells after exposure to copper $500 \mu \mathrm{M}$ (magnification: $\times 10$ ). c SKNBE cells were incubated with 1-5-10-50-100200-500 $\mu \mathrm{M}$ of copper for $72 \mathrm{~h}$. Cells were counted using the Trypan blue method (dye exclusion method). The number of viable cells was calculated and normalized to the not treated cells (value $=1$; Ctrl: control). d Cells survival (SKNBE cells) after $48 \mathrm{~h}$ of incubation. Experimental conditions (from left to right): Ctrl: control cells not exposed to copper, exposure to copper alone $500 \mu \mathrm{M}$, exposure to copper $500 \mu \mathrm{M}$ plus APV $250 \mu \mathrm{M}$, exposure to copper 500 $\mu \mathrm{M}$ plus DNQX $500 \mu \mathrm{M}$, exposure to copper $500 \mu \mathrm{M}$ plus APV $250 \mu \mathrm{M} / \mathrm{DNQX} 500$ $\mu \mathrm{M}$, and exposure to copper $500 \mu \mathrm{M}$ plus PGB $500 \mu \mathrm{M} .{ }^{*} \mathrm{p}<0.001$ referred to Ctrl; $\& \mathrm{p}<0.01$ referred to copper. $\mathrm{PGB}=$ Pregabalin.
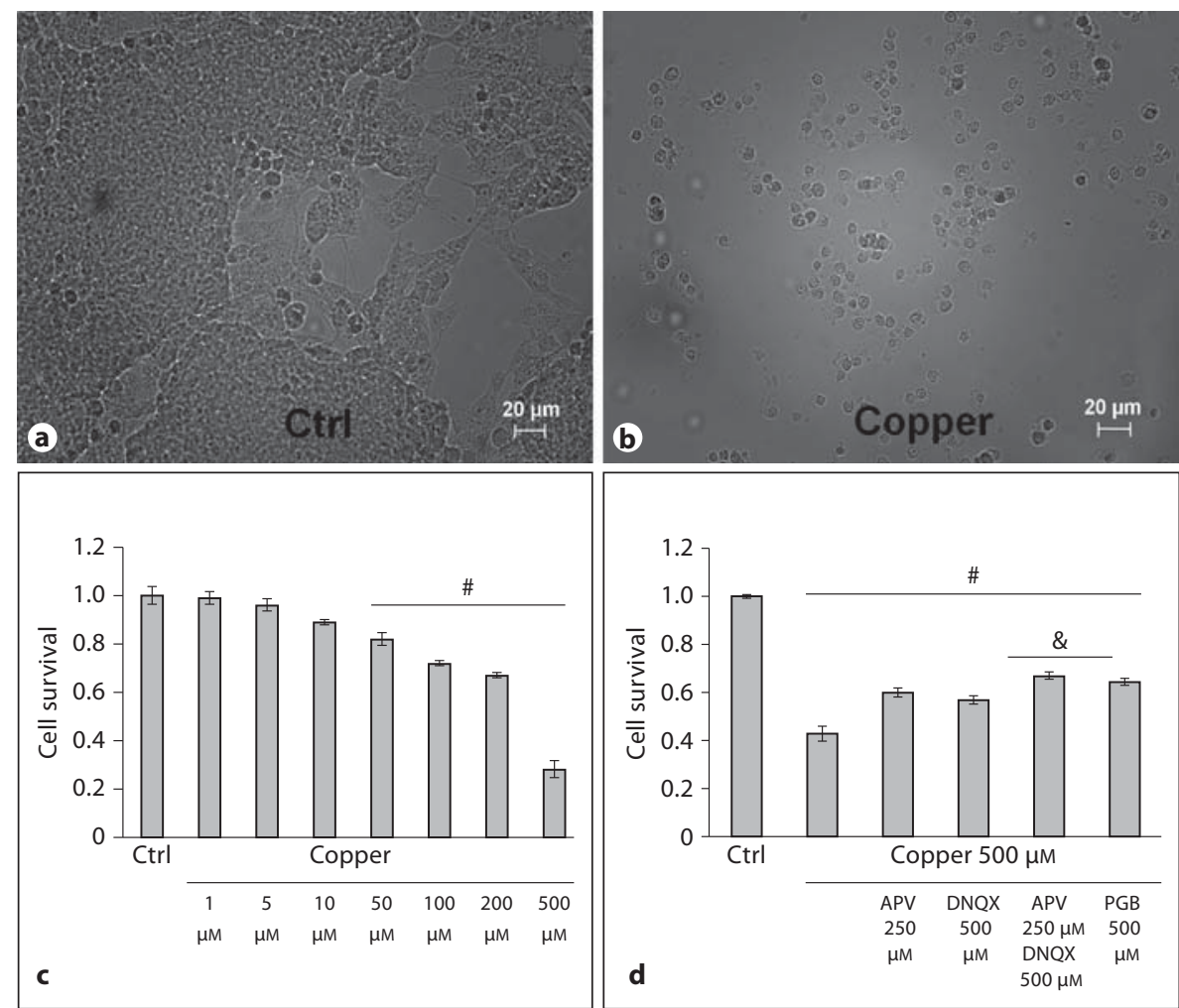

In vivo studies: To assess the effects of copper and pregabalin on NO in the motor cortex, the analysis of variance followed by post-hoc procedures was applied. For experiments with microdialysis, timing effects and group-by-time interactions were looked for. Repeated measure analysis of variance was performed, followed by post-hoc analysis. For corticomotor responses, we also applied the analysis of variance, followed by post-hoc test.

Differences with $\mathrm{p}<0.05$ were considered significant.

\section{Results}

\section{In vitro Studies}

Toxicity of Copper on Human Neuroblastoma Cells (SKNBE)

We investigated the toxic effect of copper at different times and doses. Figure 1a shows control cells not exposed to copper. An example of the toxic effect of copper is illustrated in figure $1 \mathrm{~b}$. We observed cell death with aggregates. We found a statistically significant cell death after incubation with copper at 24,48 and $72 \mathrm{~h}$ at doses of 100 , 200 and $500 \mu \mathrm{M}(\mathrm{p}<0.05)$. At $72 \mathrm{~h}$ of copper exposure, we observed a decrease in the number of cells from 1 to 0.72 with $100 \mu \mathrm{M}$ copper $(\mathrm{p}<0.05)$, from 1 to 0.67 with $200 \mu \mathrm{M}$ copper $(\mathrm{p}<0.05)$ and from 1 to 0.28 with $500 \mu \mathrm{M}$ copper $(\mathrm{p}<0.001)$. We observed a dose-dependent toxicity at 72 $\mathrm{h}$ of exposure which could be fitted exponentially $\left(\mathrm{R}^{2}=\right.$ 0.9662; fig. 1c). This was confirmed in the same experimental conditions using mouse wild-type cells from the subventricular zone (NPC-SVZ) (data not shown). Our data are in agreement with a previous observation made in M17 human neuroblastoma cells, showing that copper induces an apoptosis-mediated cell death [35]. We also investigated the in vitro protective effects of APV, DNQX, the combination APV/DNQX and pregabalin alone on the cellular toxicity induced by copper (fig. 1d). We observed that the combination of APV $250 \mu \mathrm{M} / \mathrm{DNQX} 500 \mu \mathrm{M}$, as well as pregabalin $500 \mu \mathrm{M}$ significantly increased the survival rate of cells. Cell survival increased from 0.43 (copper $500 \mu \mathrm{M})$ to 0.67 and 0.64 , respectively $(\mathrm{p}<0.001)$.

Effects of Copper on NO Production in SKNBE Cells

A significant group effect between control cells, cells exposed to copper, cells exposed to NMDA and cells exposed to copper/NMDA was found ( $\mathrm{p}<0.001)$. Following infusion of copper, NO increased to $259.72 \pm 3.46 \%$ (fig. $2 ; \mathrm{p}=0.01$ as compared to control condition). NMDA increased also markedly the concentrations of NO. Concentrations increased to $244.274 \pm 13.647 \%(\mathrm{p}=0.013)$. 
Fig. 2. Effects of copper on $\mathrm{NO}$ in vitro. Measurement of nitric oxide (NO) in SKNBE cells maintained in PBS solution at a constant temperature. Cells were incubated in a control solution alone, with copper $500 \mu \mathrm{M}$, with NMDA $10 \mathrm{mM}$, and with a combination of copper $500 \mu \mathrm{M} / \mathrm{NMDA} 10 \mathrm{mM}$. Values represent the mean \pm SD of 3 successive sets of measurements and are expressed as percentages of baseline measurements.

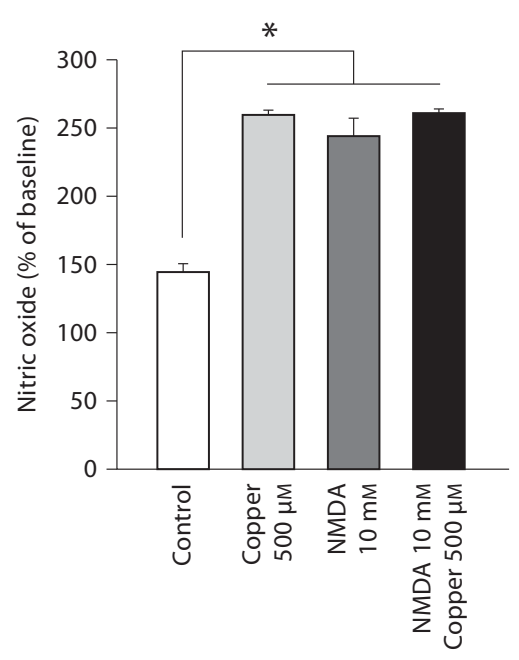

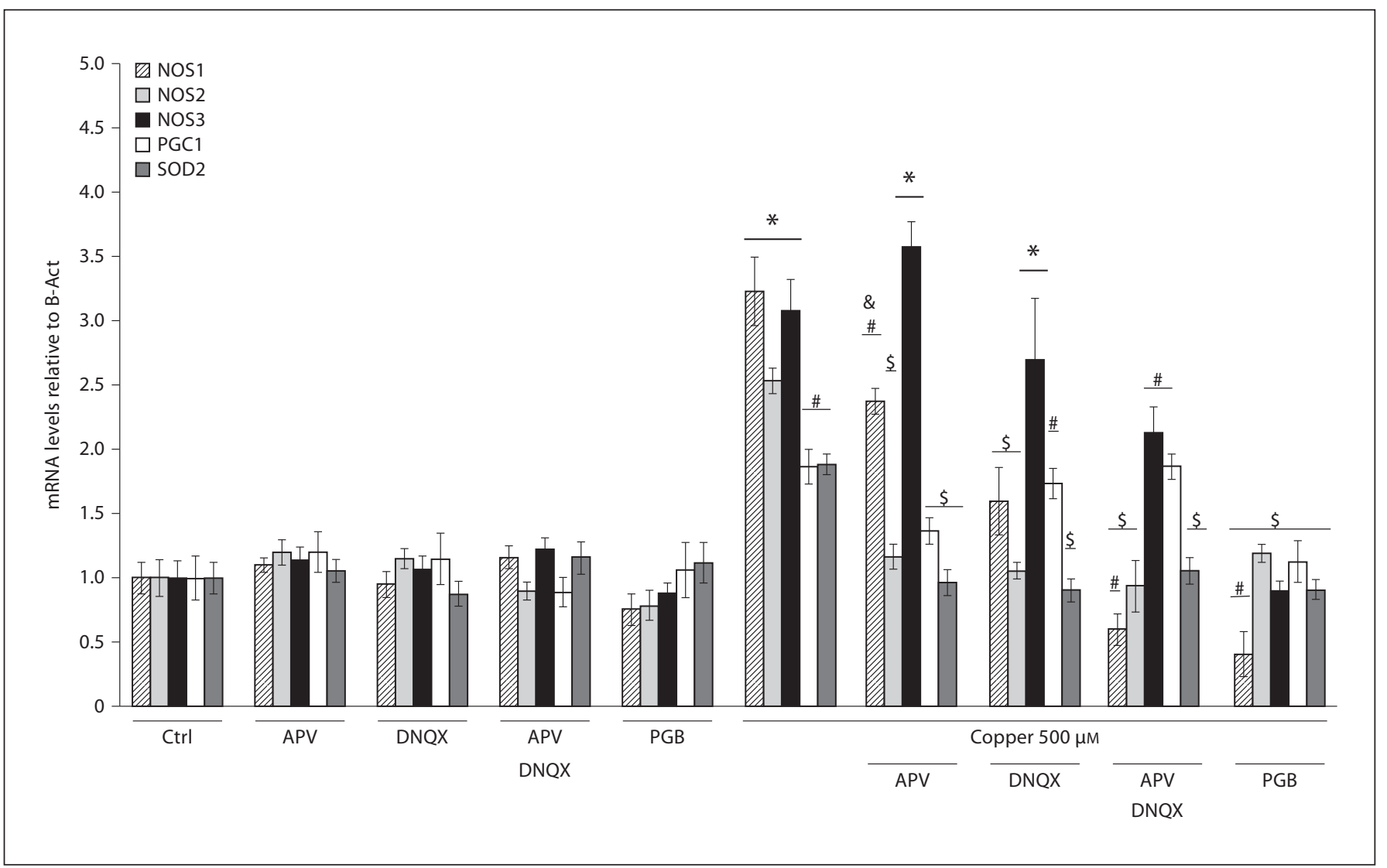

Fig. 3. Real-time PCR analysis. NOS1, NOS2, NOS3, PGC-1a and SOD2 mRNA levels after 48 h of incubation. From left to right: control cells (Ctrl), APV $250 \mu \mathrm{M}$, DNQX $500 \mu \mathrm{M}$, APV $250 \mu \mathrm{M} /$ DNQX $500 \mu \mathrm{M}$, PGB $500 \mu \mathrm{M}$, copper $500 \mu \mathrm{M}$, copper $500 \mu \mathrm{M} /$ APV $250 \mu \mathrm{M}$, copper $500 \mu \mathrm{M} / \mathrm{DNQX} 500 \mu \mathrm{M}$, copper $500 \mu \mathrm{M} /$
APV $250 \mu \mathrm{M} / \mathrm{DNQX} 500 \mu \mathrm{M}$ and copper $500 \mu \mathrm{M} / \mathrm{PGB} 500 \mu \mathrm{M}$. All the values are relative to $\beta$-actin. ${ }^{*} \mathrm{p}<0.001$ referred to ctrl; ${ }^{\#} \mathrm{p}<0.005$ referred to Ctrl; ${ }^{\$} \mathrm{p}<0.001$ referred to copper; ${ }^{\&} \mathrm{p}<$ 0.005 referred to copper. 


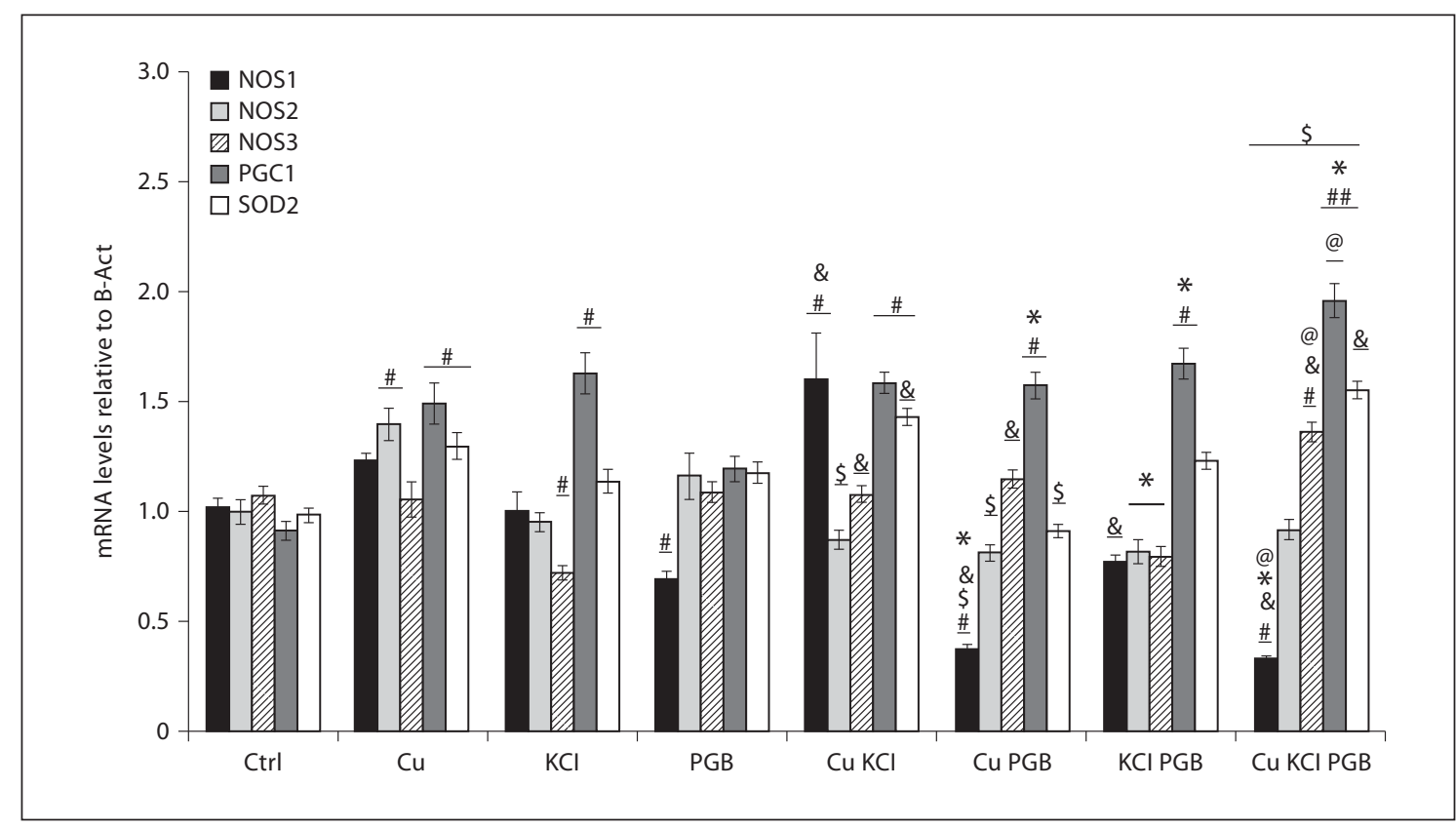

Fig. 4. Real-time PCR analysis: effects of depolarization with $\mathrm{KCl}$. NOS1, NOS2, NOS3, PGC-1a and SOD2 mRNA levels after $5 \mathrm{~h}$ of incubation with copper $(\mathrm{Cu}) 500 \mu \mathrm{M}$, potassium chloride $(\mathrm{KCl}) 20$ $\mathrm{mM}$, pregabalin (PGB) $500 \mu \mathrm{M}, \mathrm{Cu} 500 \mu \mathrm{M} / \mathrm{KCl} 20 \mathrm{~mm}, \mathrm{Cu} 500$ $\mu \mathrm{M} / \mathrm{PGB} 500 \mu \mathrm{M}, \mathrm{KCl} 20 \mathrm{mM} / \mathrm{PGB} 500 \mu \mathrm{M}, \mathrm{Cu} 500 \mu \mathrm{M} / \mathrm{KCl} 20$
$\mathrm{mM} / \mathrm{PGB} 500 \mu \mathrm{M}$. All the values are relative to $\beta$-actin. Ctrl: refers to control cells not exposed to copper. ${ }^{*} \mathrm{p}<0.005$ referred to Ctrl; \#\# $\mathrm{p}<0.001$ referred to $\mathrm{Ctrl} ;{ }^{\$} \mathrm{p}<0.001$ referred to copper; ${ }^{\&} \mathrm{p}<$ 0.001 referred to $\mathrm{KCl} ;{ }^{*} \mathrm{p}<0.001$ referred to PGB; ${ }^{@} \mathrm{p}<0.001$ referred to $\mathrm{Cu} / \mathrm{KCl}$.
In the condition NMDA plus copper, NO increased to $260.999 \pm 3.102 \%(\mathrm{p}=0.015)$, but there was no additional effect of NMDA. Our data were also confirmed in NPC-SVZ in the same experimental conditions (data not shown).

Effects of Copper and Pregabalin on mRNA in SKNBE Cells

We exposed human neuroblastoma cells to $500 \mu \mathrm{M}$ of copper for $48 \mathrm{~h}$. We observed a statistically significant increase in the expression of NOS1, NOS2, NOS3, PGC1a and SOD2 (mRNA only) (fig. 3). In particular, the level of mRNA increased from: 1 to 3.2 for NOS1 ( $p<0.001)$, 1 to 2.5 for NOS2 (p < 0.001), 1 to 3.1 for NOS3 ( $p<$ $0.001), 1$ to 1.9 for PGC-1a ( $<<0.001)$, and from 1 to 1.9 for SOD2 $(\mathrm{p}<0.001)$ as compared to control samples. We also investigated the effects of APV, DNQX, and the combination APV/DNQX on the copper-mediated NOS1-3, PGC-1a and SOD2 transcription modifications. The combination of APV $250 \mu \mathrm{M}$ and DNQX 500 $\mu \mathrm{M}$ reduced the mRNA levels of NOS1 from 3.2 to 0.6 $(\mathrm{p}<0.001)$, NOS2 from 2.5 to 0.9 ( $\mathrm{p}<0.001)$, NOS3 from 2.9 to 2.1 ( $\mathrm{p}<0.001$ ), SOD2 from 1.9 to 1 ( $\mathrm{p}<0.001$ ), by comparison with exposure to copper alone. Moreover, we investigated the effect of pregabalin $500 \mu \mathrm{M}$ after copper incubation. We found a statistically significant inhibition of copper-induced mRNA transcription activation on NOS1-3, PGC-1a and SOD2. In particular, NOS1 form dropped from $3.2 \pm 0.3$ to $0.4 \pm 0.1$ ( $\mathrm{p}<$ 0.001 ), NOS2 from $2.5 \pm 0.1$ to $1.2 \pm 0.1$, NOS3 from 3.1 \pm 0.2 to $0.9 \pm 0.2(\mathrm{p}<0.001)$, PGC-1a from $1.9 \pm 0.1$ to $1.1 \pm 0.1(\mathrm{p}<0.001), \mathrm{SOD} 2$ from $1.9 \pm 0.1$ to $0.9 \pm$ $0.1(\mathrm{p}<0.001)$.

We also studied the interaction with depolarization induced by $\mathrm{KCl} 20 \mathrm{mM}$ at $5 \mathrm{~h}$ of incubation on SKNBE cells (fig. 4). Copper at $500 \mu \mathrm{M}$ slightly increased mRNA levels of NOS2 and both PGC-1a and SOD2. KCl alone decreased significantly the mRNA levels of NOS3, whereas depolarization increased the levels of PGC-1a, as demonstrated in previous studies [24]. Pregabalin decreased the mRNA levels of NOS1. The combination of copper and $\mathrm{KCl}$ resulted in an increase in NOS1/PGC-1a/SOD2 mRNA as compared to control cells, a decrease in NOS2 mRNA as compared to copper alone, and an increase in the levels of NOS3 and SOD2 compared to $\mathrm{KCl}$ alone. Interestingly, pregabalin incubation with copper resulted 


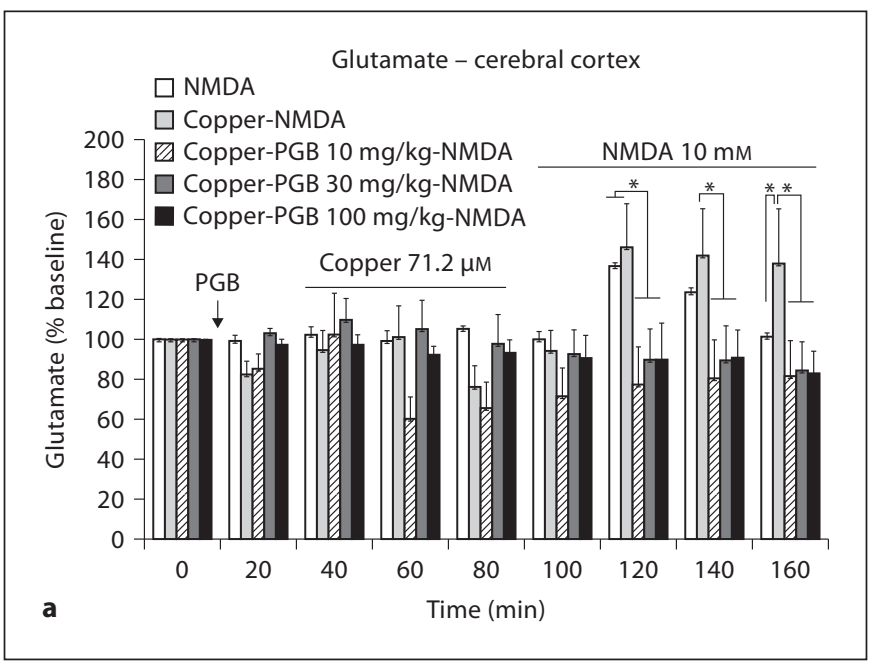

Fig. 5. Microdialysis in cerebral cortex. a Concentrations of glutamate in the extracellular space of the cerebral cortex. One control group with no administration of PGB and no administration of copper (NMDA group), one control group with no administration of PGB (copper-NMDA group), and three groups of rats receiving PGB (copper-PGB-NMDA group) are considered. The last 4 groups received an administration of copper locally by reverse dialysis prior infusion of NMDA. Note the marked increase of glutamate in controls following infusion of copper during the NMDA challenge. The addition of PGB reduces significantly the concentrations of glutamate. b Concentrations of lactate in the extracellular space of the cerebral cortex. c Concentrations of pyruvate in the extracellular space of the cerebral cortex. Values are mean \pm SEM $\left({ }^{*} \mathrm{p}<0.05\right)$. First group: $\mathrm{n}=3$ rats, second group: $\mathrm{n}=9$ rats, PGB $10 \mathrm{mg} / \mathrm{kg}: \mathrm{n}=6$, PGB $30 \mathrm{mg} / \mathrm{kg}: \mathrm{n}=5$, PGB 100 $\mathrm{mg} / \mathrm{kg}: \mathrm{n}=5$.

in a reduction of NOS1, NOS2, and SOD2 mRNA levels as compared to copper alone, but no changes were observed in PGC-1a levels. Moreover, pregabalin incubation with $\mathrm{KCl}$ showed a slight decrease in NOS1 mRNA levels as compared to $\mathrm{KCl}$. Whereas pregabalin alone did not modify mRNA levels of NOS2/NOS3, addition of $\mathrm{KCl}$ was associated with a drop in these mRNA levels, suggesting that this effect of pregabalin was sensitive to depolarization. A further combination of pregabalin, copper and $\mathrm{KCl}$, significantly reduced NOS1 mRNA levels as compared to control cells, with a robust upregulation of NOS3 and PGC-1a amount of mRNA.

\section{In vivo Studies}

Microdialysis

Copper infusion in the cerebral cortex did not change the extracellular concentrations of glutamate, but subse-
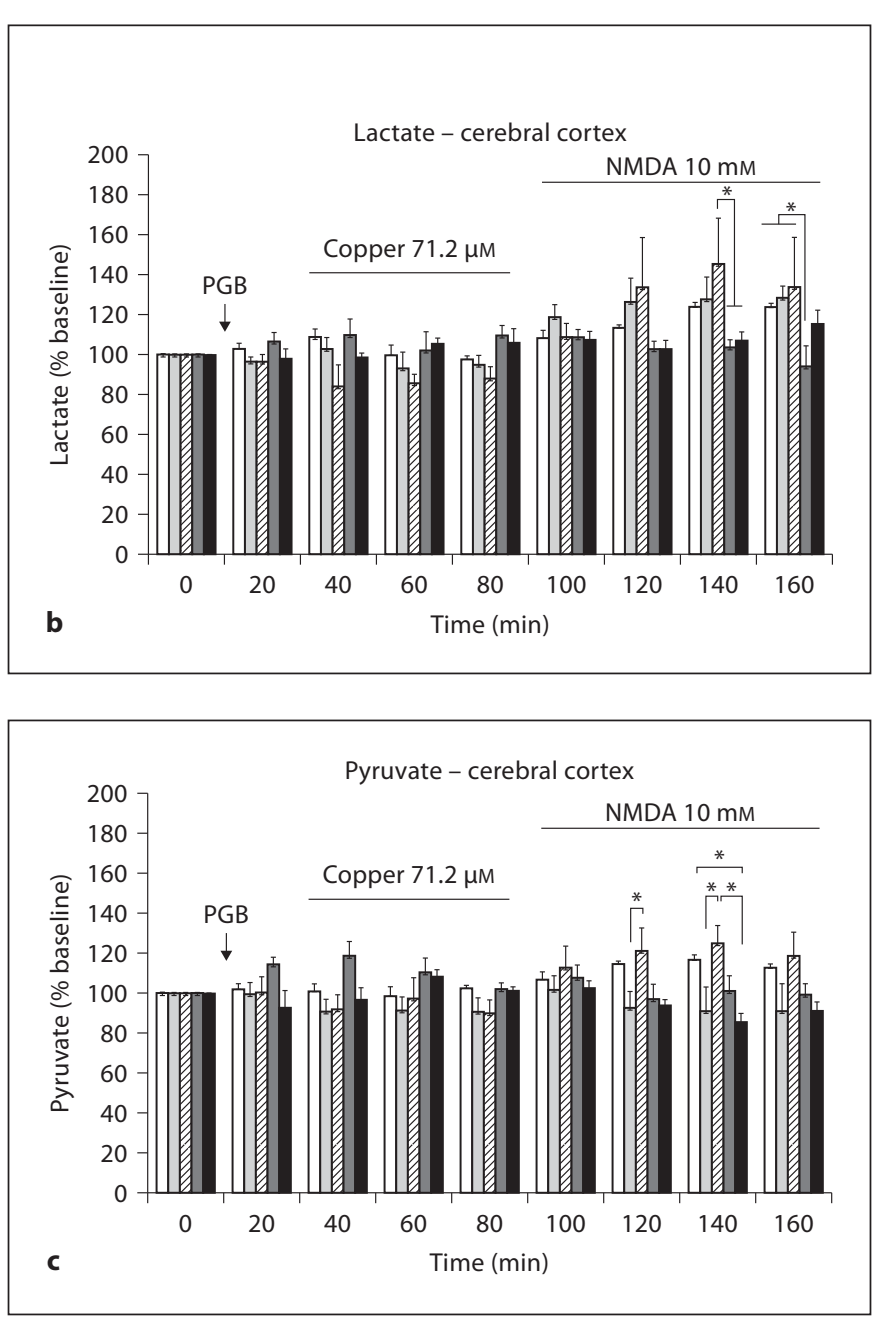

quent administration of NMDA was associated with a significant increase of glutamate concentrations (fig. 5a), indicating that copper infusion impaired markedly the NMDA-mediated turnover of glutamate in cerebral cortex [29]. Pregabalin $(10,30$ or $100 \mathrm{mg} / \mathrm{kg})$ significantly decreased the concentrations of glutamate as compared to the condition of exposure to copper alone. There was a significant group by time interaction $(\mathrm{p}=0.008)$.

We also observed that NMDA infusion increased the extracellular concentrations of glycerol (a marker of membrane turnover) in cerebral cortex in rats exposed to copper. Pregabalin reduced the levels of glycerol during the NMDA challenge (see online suppl. fig. 1, www. karger.com/doi/10.1159/000322544). However, the values were not statistically different (group by time interaction: $\mathrm{p}=0.299$ ). Glucose concentrations were not affected by infusion of copper, NMDA or pregabalin (see suppl. fig. 


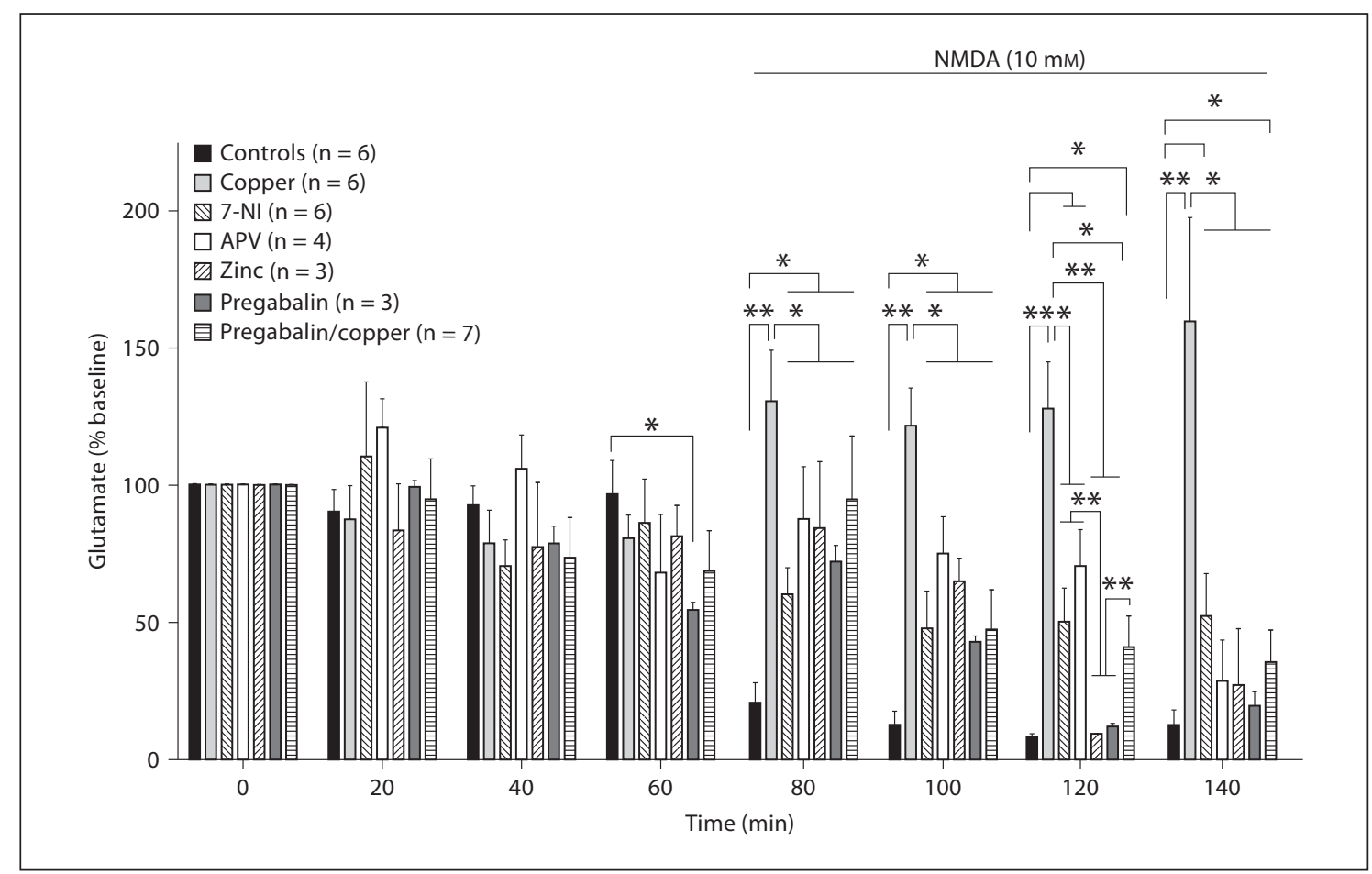

Fig. 6. Extracellular glutamate in cerebellar nuclei. Microdialysis in cerebellum. Copper $(71.2 \mu \mathrm{M}$, infusion at 20-60 min) markedly impairs the NMDA-mediated regulation of glutamate in cerebellar nuclei as compared to control rats infused with Ringer's solution. 7-Nitroindazole (7-NI; $100 \mathrm{mg} / \mathrm{kg}$ administered by the i.p. route $1 \mathrm{~h}$ prior to administration of copper), APV (50 $\mu \mathrm{M}$ in loco, administration 20 min before copper administration), zinc (14.4 $\mu \mathrm{M}$ administered in loco between copper and NMDA), pregabalin alone (administered i.p. $30 \mathrm{mg} / \mathrm{kg}$ at $20 \mathrm{~min}$ ) and pregabalin (administered i.p. $30 \mathrm{mg} / \mathrm{kg}$ during copper infusion) antagonized the effect of copper. Values are mean \pm SEM. ${ }^{*} \mathrm{p}<0.05$; ${ }^{* *} \mathrm{p}<0.01$.
2). The analysis of variance showed a group by time interaction with a $\mathrm{p}$ value of 0.206 . We found a significant group by time interaction for lactate (fig. $5 b ; p=0.001$ ). In particular, at $160 \mathrm{~min}$, lactate levels were significantly lower in the group receiving pregabalin at a dose of 30 $\mathrm{mg} / \mathrm{kg}$ as compared to controls. Levels of pyruvate in the extracellular space were higher with a dose of pregabalin of $10 \mathrm{mg} / \mathrm{kg}$, as compared to control rats or the group receiving a dose of pregabalin $100 \mathrm{mg} / \mathrm{kg}$ (fig. $5 \mathrm{c}$; group by time interaction: $p=0.001$ ). Concentrations of pyruvate were similar with a dose of pregabalin of 30 or $100 \mathrm{mg} / \mathrm{kg}$ as compared to controls.

In cerebellar nuclei, administration of copper severely impaired the NMDA-mediated regulation of glutamate (fig. 6). Inhibition of NOS with 7-NI, administration of APV, zinc, and pregabalin had a favorable effect upon the NMDA-mediated regulation of glutamate. Interestingly, the concomitant administration of pregabalin with copper restored partially the NMDA-mediated regulation.

Reducing Copper Toxicity with Pregabalin
Effects of Copper and Pregabalin on NO in vivo

A significant group by time interaction was found for the measurements of NO in motor cortex $(p<0.001$; fig. 7). Copper increased markedly the levels of $\mathrm{NO}(\mathrm{p}<$ 0.001 ). Pregabalin $30 \mathrm{mg} / \mathrm{kg}$ i.p. antagonized this rise, suggesting a contribution of the release of pre-synaptic glutamate in the rise of $\mathrm{NO}$ concentrations. The values of NO were significantly lower when pregabalin was administered prior to copper $(\mathrm{p}<0.001)$. Although pregabalin decreased the levels of $\mathrm{NO}$, the concentration remained higher at 50 and $60 \mathrm{~min}$ as compared to the control condition (intergroup effect: $\mathrm{p}=0.002$ ).

\section{Neurophysiological Studies}

Infusion of copper in cerebellar nuclei was associated with a marked increase in the amplitudes of corticomotor responses (fig. 8), suggesting a disinhibition of cerebellar nuclei [32]. Pregabalin alone did not induce any statistically significant change in the amplitudes of corticomotor responses $(p=0.53)$, but antagonized the effects of copper 
Fig. 7. Effects of copper on NO concentrations in the motor cortex. Controls: infusion of Ringer's solution; copper: infusion of copper $71.2 \mu \mathrm{M}$ in motor cortex at $20-$ 60 min; pregabalin: pregabalin administered at a dose of $30 \mathrm{mg} / \mathrm{kg}$ i.p. at $0 \mathrm{~min}$; pregabalin/copper: pregabalin administered at a dose of $30 \mathrm{mg} / \mathrm{kg}$ i.p. at $0 \mathrm{~min}$ followed by infusion of copper $71.2 \mu \mathrm{M}$ in the motor cortex at 20-60 min. Values are mean $\pm \mathrm{SD}$ and are expressed as percentages of baseline measurements. $\mathrm{n}=4$ rats in each group. ${ }^{*} \mathrm{p}<0.05 ;{ }^{* *} \mathrm{p}<0.01$.

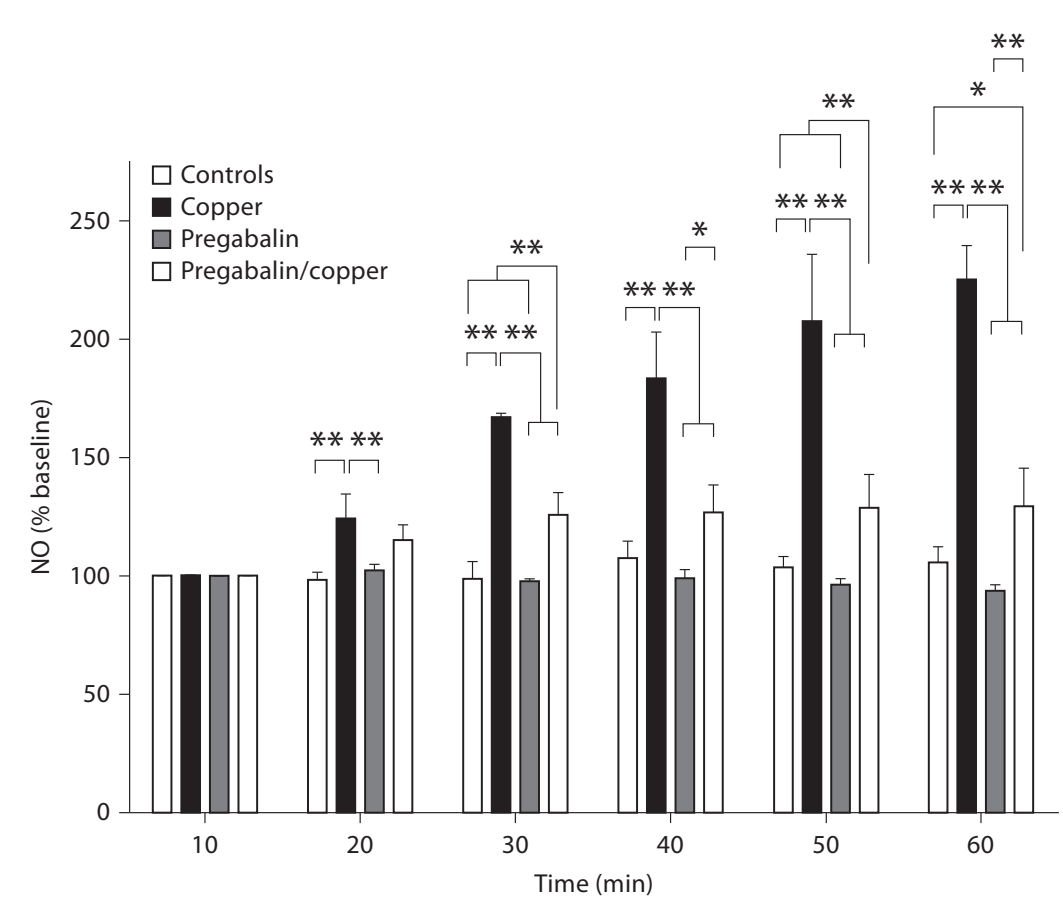

on the amplitudes of corticomotor responses. The analysis of variance revealed a significant group effect $(\mathrm{p}=$ 0.033 ), and a significant group-by-time interaction ( $\mathrm{p}<$ $0.001)$. At $30 / 40 / 50 \mathrm{~min}$, the amplitudes of corticomotor responses were higher in the copper group as compared to the pregabalin group ( $\mathrm{p}<0.05)$; at $50 \mathrm{~min}$, the amplitudes of corticomotor responses were significantly higher in the copper group as compared to the control group (Ringer), or the pregabalin/copper group $(\mathrm{p}<0.05)$.

\section{Discussion}

We show that high doses of copper strongly increase NO production, a key molecule for signaling. We also demonstrate that copper induces an increase in the transcription of the NOS1-3, PGC-1a and SOD2 genes. The combination of APV and DNQX prevents the transcription activation of the NOS enzymes, PGC-1a and SOD2. We also show that pregabalin increases cell survival during copper exposure, antagonizes the increase of transcription of NOS1-3 and restores the NMDA-mediated regulation of glutamate in the brain. We also confirm recent data demonstrating that depolarization induces an upregulation of PGC-1a mRNA [24] and we show that the pregabalin effect on transcription of NOS2/NOS3 is sensitive to $\mathrm{KCl}$-induced depolarization.

What is the mechanism inducing cell death by high doses of copper? The mechanism is multifactorial. Three main factors contribute: the interaction with membrane receptors, the activation of NO pathways and the mitochondrial toxicity. It has been demonstrated that copper interacts directly with ionotropic receptors on cellular membranes. In particular, copper interacts with the NMDA receptor [36, 37]. We have observed that NMDA and AMPA antagonists partially protect cells from copper toxicity, confirming that the effects of copper are mediated by NMDA and AMPA pathways. Moreover, copper strongly activates NO pathways and generates a nitrosative stress [38]. NOS1 and NOS3 produce low fluxes of NO for short periods of time, whereas NOS2 generates large amounts of NO for several hours. Copper administration results in overproduction of superoxide, and leads to synthesis of peroxynitrite, which is highly toxic [3842]. Copper overload induces also a marked mitochondrial dysfunction and impairs the activity of key mitochondrial and cytosolic enzymes involved in energy metabolism [10-12].

How does pregabalin antagonize the toxicity of copper? We provide 3 possible explanations. First, our results 

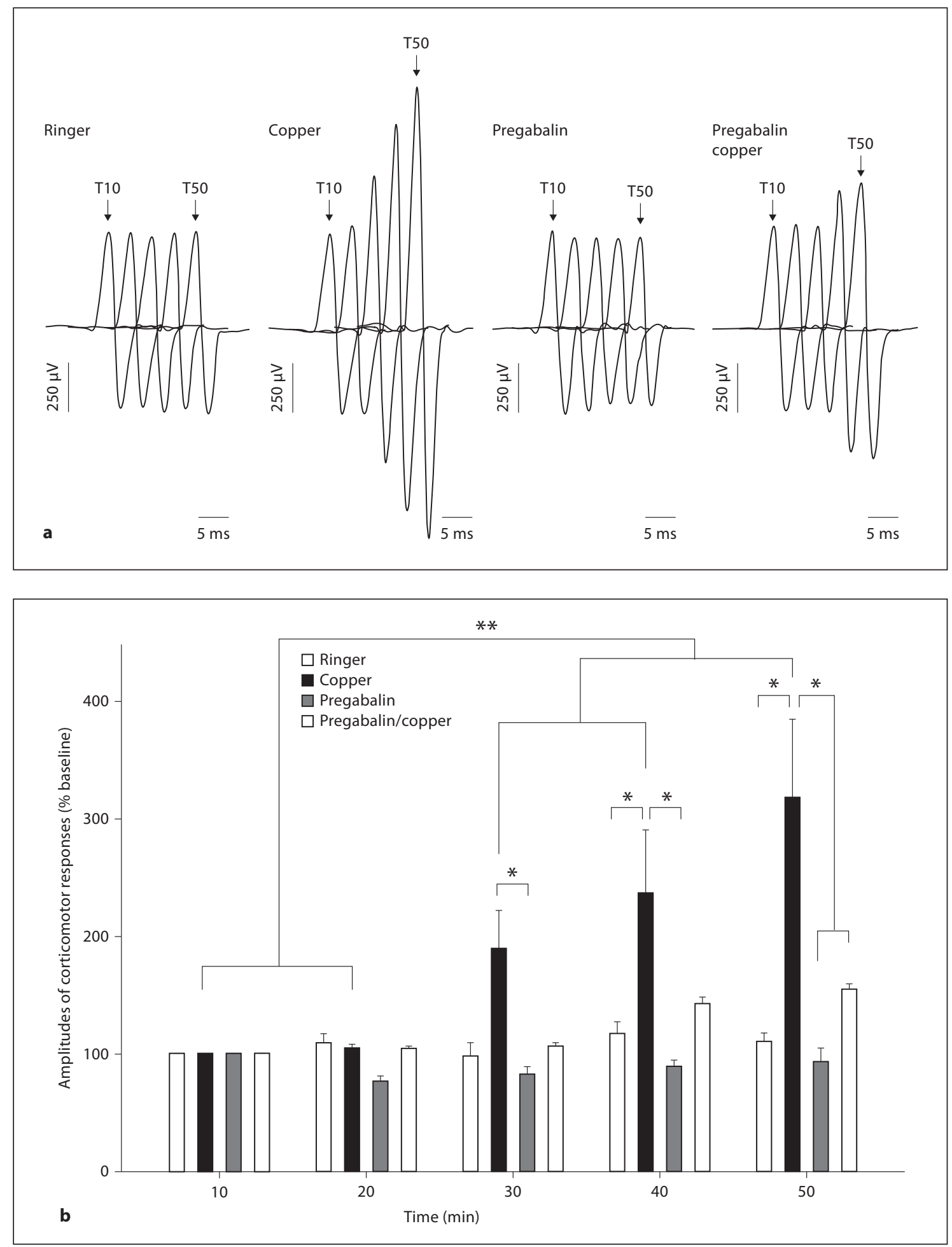

Fig. 8. a, b Effects of infusion of copper $71.2 \mu \mathrm{M}$ in left cerebellar nuclei on the amplitudes of corticomotor responses in left gastrocnemius muscle (stimulation of right motor cortex). a Illustration of corticomotor responses from T10 min to T50 min in the 4 experimental conditions. Ringer: infusion of Ringer's solution (controls); copper: infusion of copper 71.2 $\mu \mathrm{M}$ at 20-50 min; pre- gabalin: pregabalin administered at a dose of $30 \mathrm{mg} / \mathrm{kg}$ i.p. at $0 \mathrm{~min}$; pregabalin/copper: pregabalin administered at a dose of 30 $\mathrm{mg} / \mathrm{kg}$ i.p. at $0 \mathrm{~min}$ followed by infusion of copper at 20-50 min. Values are mean \pm SEM and expressed as percentages of baseline measurements. Ringer: $\mathrm{n}=5$ rats, copper: $\mathrm{n}=6$ rats, pregabalin: $\mathrm{n}=4$ rats, pregabalin + copper: $\mathrm{n}=4$ rats. ${ }^{*} \mathrm{p}<0.05 ;{ }^{*} \mathrm{p}<0.01$. 
can be evaluated at the light of the mechanism of action of pregabalin at a presynaptic level. Indeed, a main hypothesis for pregabalin activity is the reduction of calcium influx by an interaction with the alpha2delta subunit of presynaptic VGCC. We argue that pregabalin antagonizes the increase of transmitters and metabolites released during excitotoxicity, mainly glutamate and indirectly glycerol. It is established that glutamate in excess is toxic to neurons. Increased concentrations of glutamate overactivate ionotropic glutamate receptors, triggering cell death [43]. The resulting increase in intracellular free calcium is sequestered mainly by mitochondria, causing a disruption of ATP synthesis impairing redox state. Noteworthy, the mitochondria are the main site of uptake of calcium following activation of the NMDA receptor [43]. Levels of glycerol in the extracellular space are a marker of membrane turn-over and are used to evaluate the degree of brain damage in vivo in case of cellular injury [44]. In models of occlusion-reperfusion, glycerol concentrations increase markedly in the zone of infarction and in the penumbra. Extracellular concentrations of glycerol are surrogate markers of the levels of ischemia. Sustained increase of interstitial glycerol indicates severe ischemia, whereas transient increases suggest a penumbra situation [44]. Malignant evolution in stroke models are associated with increased levels of glutamate and higher lactate/pyruvate ratios [45].

The second explanation on the neuroprotective effect of pregabalin is the modulation of glutamate transporters. Indeed, it has been shown recently in studies with human neocortical synaptosomes that one of the modes of action of pregabalin is the interaction with the activity of uptake transporters which transfer the neurotransmitter from the synaptic cleft back to the cytoplasm of neurons and glial cells [46]. These transporters utilize transmembrane ion gradients to transport their substrates. However, when ion gradients decrease, transporters reverse and release the neurotransmitter in a calcium-independent manner $[46,47]$. Such a situation is likely to occur in case of copper toxicity due to the disturbances in energy metabolism.

ATP-sensitive $\mathrm{K}^{+}$channels provide a link between the electrical activity of cell membranes and cellular metabolism [48]. These channels open in states of ATP deficiency, rendering neurons resistant to stress by a phenomenon of hyperpolarization. Huang et al. [49] have demonstrated that pregabalin activates these channels in a concentration-dependent fashion. This activation impedes glutamatergic transmission both on the presynaptic and postsynaptic levels, reducing the excitability of neurons. This could be a third mechanism of action to explain the antagonistic effects of pregabalin upon copper toxicity.

PPARs are members of a nuclear receptors superfamily activated by fatty acids, eicosanoids and other synthetic ligands [50]. Activated PPARs bind specific cis-element (PPRE) of DNA in the promoter/regulative regions of target genes and modulate their transcription $[51,52]$. PPAR- $\gamma$ plays a key role in numerous cellular functions and its altered regulation leads to several diseases [53]. The effects of PPAR- $\gamma$ activation are mediated by the recruitment of its coactivator PGC-1a binding to PPAR- $\gamma$, allowing the interaction with $\mathrm{CBP} / \mathrm{p} 300$, a protein with histone acetyltransferase activity (HAT) [54]. PGC-1a is highly expressed in tissues having a high-energy demand, such as brown adipose tissue, heart, skeletal muscle and brain. Interestingly, PGC-1a is a master regulator of mitochondrial biogenesis and cell respiration $[51,52]$. The effect on mitochondrial biogenesis is mediated by the co-activation of ERR- $\alpha, \mathrm{NRF}-1$ and NRF-2 [55]. PGC-1a is also required for the induction of many ROS-detoxifying enzymes including GPX-1 and SOD2 [56, 57]. Interestingly, calcium channels are also mediators of PGC-1a activation [58]. Influx of calcium via VGCC up-regulates PGC-1a transcripts and proteins in neurons [59]. This is followed by an increase in neuronal activity [24]. The coupling between calcium channels activation, depolarization of neurons and increased gene expression appears as a main mechanism of regulation of transcription factors not only in neurons, but also in other cell types where cytosolic calcium triggers a calcium/calmodulin-dependent protein kinase signaling [60-63]. Decreases in ATP/ADP ratios following enhanced energy expenditure, impaired mitochondrial metabolism and inflammatory responses contribute to the stimulation of PGC-1a via activation of the p38 MAPK, which could represent a vital upstream regulator in signaling the activation of PGC-1a in neurons [58, 64, 65]. The interaction $\mathrm{p} 38 \mathrm{MAPK} /$ pregabalin deserves further studies.

In summary, copper impacts on signaling cascades related to glutamate and NO. Exposure to copper stimulates the transcription of NOS1-3, which results in increased production of NO and impairs the NMDA-mediated regulation of glutamate. Excess of glutamate contributes also to the stimulation of NOS. Pregabalin acts on several pathways, including on the alpha2delta subunit of the VGCC, reducing the concentrations of glutamate, the expression of PGC-1a and preventing the excitotoxic cascade. Taken together, these results suggest that pregabalin could be used in disorders of copper homeo- 
stasis associated with neurological deficits, such as Wilson disease. Pregabalin could be seen as a regulator of neuronal function in disturbances of metal ions homeostasis. This study provides support for further works in the area of neurodegenerative diseases with pharmacological agents acting like pregabalin.

\section{Acknowledgments}

M.M. is supported by FNRS-Belgium. D.M. is receiving a fellowship from Fonds Erasme, Belgium. This work was supported by a grant from Pfizer (USA).

\section{References}

1 Choi BS, Zheng W: Copper transport to the brain by the blood-brain barrier and bloodCSF barrier. Brain Res 2009;1248:14-21.

$\checkmark 2$ Popescu BF, Robinson CA, Rajput A, et al: Iron, copper, and zinc distribution of the cerebellum. Cerebellum 2009;8:74-79.

$>3$ Gaggelli E, Kozlowski H, Valensin D, et al: Copper homeostasis and neurodegenerative disorders (Alzheimer's disease, prion, and Parkinson's diseases and amyotrophic lateral sclerosis). Chem Rev 2006;106:1995-2044.

$\checkmark 4$ Rae TD, Schmidt PJ, Pufahl RA, et al: Undetectable intracellular free copper: the requirement of a copper chaperone for superoxide dismutase. Science 1999;284:805-808.

$\checkmark 5$ Linder MC, Hazegh-Azam M: Copper biochemistry and molecular biology. Am J Clin Nutr 1996;63:797-811.

$\checkmark 6$ Tandy S, Williams M, Leggett A, et al: Nramp2 expression is associated with $\mathrm{pH}$ dependent iron uptake across the apical membrane of human intestinal Caco-2 cells. J Biol Chem 2000;275:1023-1029.

$>7$ Lutsenko S, Efremov RG, Tsivkovskii R, Walker JM: Human copper-transporting ATPase ATP7B (the Wilson's disease protein): biochemical properties and regulation. J Bioenerg Biomembr 2002;34:351-362.

$\checkmark 8$ Donnelly PS, Xiao Z, Wedd AG: Copper and Alzheimer's disease. Curr Opin Chem Biol 2007;11:128-133.

9 Barnham KJ, Masters CL, Bush AI: Neurodegenerative diseases and oxidative stress. Nat Rev Drug Discov 2004;3:205-214.

-10 Sokol RJ, Devereaux MW, O’Brien K, et al: Abnormal hepatic mitochondrial respiration and cytochrome $\mathrm{C}$ oxidase activity in rats with long-term copper overload. Gastroenterology 1993;105:178-187.

-11 Britton RS: Metal-induced hepatotoxicity. Semin Liver Dis 1996;16:3-12.

12 Sheline CT, Choi DW: $\mathrm{Cu}^{2+}$ toxicity inhibition of mitochondrial dehydrogenases in vitro and in vivo. Ann Neurol 2004;55:645653.

13 White AR, Multhaup G, Maher F, et al: The Alzheimer's disease amyloid precursor protein modulates copper-induced toxicity and oxidative stress in primary neuronal cultures. J Neurosci 1999;19:9170-9179.

14 Schilsky ML: Wilson disease: current status and the future. Biochimie 2009;91:12781281 .
15 Sokol RJ, Twedt D, McKim JM Jr, et al: Oxidant injury to hepatic mitochondria in patients with Wilson's disease and Bedlington terriers with copper toxicosis. Gastroenterology 1994;107:1788-1798.

16 Sternlieb I, Feldmann G: Effects of anticopper therapy on hepatocellular mitochondria in patients with Wilson's disease: an ultrastructural and stereological study. Gastroenterology 1976;71:457-461.

17 Wiedau-Pazos M, Goto JJ, Rabizadeh S, et al: Altered reactivity of superoxide dismutase in familial amyotrophic lateral sclerosis. Science 1996;271:515-518.

18 Huang X, Atwood CS, Hartshorn MA, et al: The A beta peptide of Alzheimer's disease directly produces hydrogen peroxide through metal ion reduction. Biochemistry 1999;38: 7609-7616.

$19 \mathrm{Lu}$ J, Zheng YL, Wu DM, et al: Trace amounts of copper induce neurotoxicity in the cholesterol-fed mice through apoptosis. FEBS Lett 2006;580:6730-6740.

20 Duflou H, Maenhaut W, De Reuck J: Regional distribution of potassium, calcium, and six trace elements in normal human brain. Neurochem Res 1989;14:1099-1112.

-21 Popescu BF, Robinson CA, Chapman LD, Nichol H: Synchrotron X-ray fluorescence reveals abnormal metal distributions in brain and spinal cord in spinocerebellar ataxia: a case report. Cerebellum 2009;8: 340-351.

22 Micheva KD, Taylor CP, Smith SJ: Pregabalin reduces the release of synaptic vesicles from cultured hippocampal neurons. Mol Pharmacol 2006;70:467-476.

23 Biedler JL, Roffler-Tarlov S, Schachner M, et al: Multiple neurotransmitter synthesis by human neuroblastoma cell lines and clones. Cancer Res 1978;38:3751-3757.

24 Liang HL, Dhar SS, Wong-Riley MT: p38 mitogen-activated protein kinase and calcium channels mediate signaling in depolarization-induced activation of peroxisome proliferator-activated receptor gamma coactivator-1alpha in neurons. J Neurosci Res 2010;88:640-649.

25 Livak KJ, Schmittgen TD: Analysis of relative gene expression data using real-time quantitative PCR and the 2(-Delta Delta C(T)) method. Methods 2001;25:402-408.
26 Alvarez S, Moldovan M, Krarup C: Acute energy restriction triggers Wallerian degeneration in mouse. Exp Neurol 2008;212:166178.

27 Manto M, Laute MA: A possible mechanism for the beneficial effect of ethanol in essential tremor. Eur J Neurol 2008;15:697-705.

28 Cais O, Sedlacek M, Horak M, et al: Temperature dependence of NR1/NR2B NMDA receptor channels. Neuroscience 2008;151: 428-438.

29 Manto MU, Laute MA, Aguera M, Rogemond V, Pandolfo M, Honnorat J: Effects of anti-glutamic acid decarboxylase antibodies associated with neurological diseases. Ann Neurol 2007;61:544-551.

30 Wall M: A role for zinc in cerebellar synaptic transmission? Cerebellum 2005;4:224-229.

31 Kitamura Y, Iida Y, Abe J, et al. : In vivo measurement of presynaptic $\mathrm{Zn}^{2+}$ release during forebrain ischemia in rats. Biol Pharm Bull 2006;29:821-823.

>32 Oulad Ben Taib N, Manto M: Effects of trains of high-frequency stimulation of the premotor/supplementary motor area on conditioned corticomotor responses in hemicerebellectomized rats. Exp Neurol 2008;212: 157-165.

33 Molina-Luna K, Buitrago MM, Hertler B, et al: Cortical stimulation mapping using epidurally implanted thin-film microelectrode arrays. J Neurosci Meth 2007;161:118-125.

34 Oulad Ben Taib N, Manto M, et al: Hemicerebellectomy blocks the enhancement of cortical motor output associated with repetitive somatosensory stimulation. J Physiol (Lond) 2005;567:293-300.

35 Chan HW, Liu T, Verdile G, et al: Copper induces apoptosis of neuroblastoma cells via post-translational regulation of the expression of Bcl-2-family proteins and the $\mathrm{tx}$ mouse is a better model of hepatic than brain $\mathrm{Cu}$ toxicity. Int J Clin Exp Med 2008;1:7688.

36 Schlief ML, Craig AM, Gitlin JD: NMDA receptor activation mediates copper homeostasis in hippocampal neurons. J Neurosci 2005;25:239-246.

37 Trombley PQ, Shepherd GM: Differential modulation by zinc and copper of amino acid receptors from rat olfactory bulb neurons. J Neurophysiol 1996;76:2536-2546. 
38 Cuzzocrea S, Mazzon E, Dugo L, et al: Reduction in the evolution of murine type II collagen-induced arthritis by treatment with rosiglitazone, a ligand of the peroxisome proliferator-activated receptor gamma. Arthritis Rheum 2003;48:3544-3556.

$\checkmark 39$ Beckman JS, Beckman TW, Chen J, et al: Apparent hydroxyl radical production by peroxynitrite: implications for endothelial injury from nitric oxide and superoxide. Proc Natl Acad Sci USA 1990;87:1620-1624.

40 Dedon PC, Tannenbaum SR: Reactive nitrogen species in the chemical biology of inflammation. Arch Biochem Biophys 2004 423:12-22.

41 Goldstein S, Lind J, Merényi G: Chemistry of peroxynitrites as compared to peroxynitrates. Chem Res 2005;105:2457-2470.

-42 Ferrer-Sueta G, Radi R: Chemical biology of peroxynitrite: kinetics, diffusion, and radicals. ACS Chem Biol 2009;4:161-177.

43 Greenwood SM, Connolly CN: Dendritic and mitochondrial changes during glutamate excitotoxicity. Neuropharmacology 2007;53:891-898.

-44 Frykholm P, Hillered L, Langstrom B, et al: Increase of intersticial glycerol reflects the degree of ischemic brain damage: a PET and microdialysis study in a middle cerebral artery occlusion-reperfusion primate model. J Neurol Neurosurg Psychiatry 2001;71:455461.

-45 Dohmen C, Bosche B, Graf R, et al: Prediction of malignant course in MCA infarction by PET and microdialysis. Stroke 2003;34: 2152-2158.

-46 Brawek B, Löffler M, Weyerbrock A, Feuerstein TJ: Effects of gabapentin and pregabalin on $\mathrm{K}^{+}$-evoked ${ }^{3} \mathrm{H}$-GABA and ${ }^{3} \mathrm{H}$-glutamate release from human neocortical synaptosomes. Arch Pharmacol 2009;379:361-369.
47 Richerson GB, Wu Y: Dynamic equilibrium of neurotransmitter transporters: not just for reuptake anymore. J Neurophysiol 2003;90: 1363-1374.

48 Ashcroft FM, Gribble FM: Correlating structure and function in ATP-sensitive $\mathrm{K}^{+}$channels. Trends Neurosci 1998;21:288-294.

49 Huang CW, Huang CC, Wu SN: The opening effect of pregabalin on ATP-sensitive potassium channels in differentiated hippocampal neuron-derived H19-7 cells. Epilepsia 2006;47:720-726.

50 Blanquart C, Barbier O, Fruchart J, et al: Peroxisome proliferator-activated receptors: regulation of transcriptional activities and roles in inflammation. J Steroid Biochem Mol Biol 2003;85:267-273.

$51 \mathrm{Wu} \mathrm{Z}$, Puigserver P, Andersson U, et al: Mechanisms controlling mitochondrial biogenesis and respiration through the thermogenic coactivator PGC-1. Cell 1999;98:115124.

52 Kelly DP, Scarpulla RC: Transcriptional regulatory circuits controlling mitochondrial biogenesis and function. Genes Dev 2004;18: 357-368.

53 Heneka MT, Landreth GE: PPARs in the brain. Biochim Biophys Acta 2007;1771: 1031-1045.

54 Torchia J, Rose DW, Inostroza J, et al: The transcriptional co-activator p/CIP binds CBP and mediates nuclear-receptor function. Nature 1997;387:677-684.

55 Mootha VK, Handschin C, Arlow D, et al: Erralpha and Gabpa/b specify PGC-1alphadependent oxidative phosphorylation gene expression that is altered in diabetic muscle. Proc Natl Acad Sci USA 2004;101:65706575 .

56 St-Pierre J, Drori S, Uldry M, et al: Suppression of reactive oxygen species and neurodegeneration by the PGC-1 transcriptional coactivators. Cell 2006;127:397-408.
57 Valle I, Alvarez-Barrientos A, Arza E, et al: PGC-1\{alpha\} regulates the mitochondrial antioxidant defense system in vascular endothelial cells. Cardiovasc Res 2005;66:562573.

58 Liang HL, Dhar SS, Wong-Riley MT: p38 mitogen-activated protein kinase and calcium channels mediate signaling in depolarization-induced activation of peroxisome proliferator-activated receptor gamma coactivator-1alpha in neurons. J Neurosci Res 2010;88:640-649.

59 Striessnig J, Koschak A, Sinnegger-Brauns MJ: Role of voltage-gated L-type $\mathrm{Ca}^{2+}$ channel isoforms for brain function. Biochem Soc Trans 2006;34:903-909.

-60 Baldassa S, Zippel R, Sturani E: Depolarization-induced signaling to Ras, Rapl and MAPKs in cortical neurons. Brain Res Mol Brain Res 2003;119:111-122.

61 Impey S, Obrietan K, Wong ST, et al: Cross talk between ERK and PKA is required for $\mathrm{Ca} 2+$ stimulation of CREB-dependent transcription and ERK nuclear translocation. Neuron 1998;21:869-883.

62 Wright DC: Mechanisms of calcium-induced mitochondrial biogenesis and GLUT4 synthes. Appl Physiol Nutr Metabol 2007;32: 840-845.

63 Knutti D, Kralli A: PGC-1, a versatile coactivator. Trends Endocrinol Metab 2001;12: 360-365.

64 Puigserver P, Rhee J, Lin J, et al: Cytokine stimulation of energy expenditure through p38 MAP kinase activation of PPARgamma coactivator-1. Mol Cell 2001;8:971-982.

-65 Arany Z, He H, Lin J, et al: Transcriptional coactivator PGC-1 alpha controls the energy state and contractile function of cardiac muscle. Cell Metab 2005;1:259-271. 